\title{
Insecticidal activity of alpha-cypermethrin against small banded pine weevil Pissodes castaneus (Coleoptera: Curculionidae) in forest plantations and thickets
}

\author{
Aleksandra Prokocka, Iwona Skrzecz $\bowtie$, Alicja Sowińska, Robert Wolski, \\ Wojciech Janiszewski
}

Forest Research Institute, Department of Forest Protection, Sękocin Stary, Braci Leśnej 3, 05-090 Raszyn, Poland, phone: 4822 7150541, e-mail: i.skrzecz@ibles.waw.pl

\section{Abstract}

Scots pine (Pinus sylvestris) plantations and thickets damaged by biotic and abiotic factors are particularly attractive to small-banded pine weevil Pissodes castaneus, whose larvae excavate feeding tunnels in the stems of young trees, causing their death. There are no chemical methods that can be applied to protect forest plantations and thickets against this pest. Therefore, the studies were undertaken aimed at the assessment of the efficacy of alpha-cypermethrin used to reduce the numbers of this pest within restock areas. The scope of work included laboratory and field estimation of insecticidal activity of alpha-cypermethrin.

In laboratory, the beetles of $P$. castaneus were reared on $P$. sylvestris twigs treated with five concentrations of alpha-cypermethrin (0.0001-1\%) formulated as Fastac Forest 15 SC. Insect mortality was calculated during 7-day rearing and median lethal concentration $\mathrm{LC}_{50}$ was calculated. The field treatments consisted of spraying of four-year old Scots pines with the insecticide in concentrations of $2 \%$ and $4 \%$.

In laboratory conditions, the insecticide used at five different concentrations caused a $7-95 \%$ mortality of the beetles $\left(\mathrm{LC}_{50}=0.266 \%\right)$, while field sprays resulted in a $1.5-3.5$-fold reduction in the colonization of trees and in higher pest mortality rates.

The results indicate the possibility of using of alpha-cypermethrin in protecting the forest against P. castaneus and can be the basis for the development of chemical method used in the forestry practice.

\section{KeY WORDS}

Pissodes castaneus, alpha-cypermethrin, $\mathrm{LC}_{50}$, spray treatments

\section{INTRODUCTION}

The banded pine weevil Pissodes castaneus (De Geer.) (Coleoptera, Curculionidae) is one of most dangerous pests in forest plantations and thickets weakened by root fungi, deer and abiotic factors (e.g. improper planting, drought, hail) (Alauzet 1990). The beetles leave their wintering places in the first half of April and then feed on the buds and young shoots of Scots pine Pinus sylvestris L. trees. In the case of mass occurrence, it can 
lead to inhibited shoot growth and general weakening of trees. In May, the female beetles lay their eggs on the lower parts of Scots pine stems. The larvae that feed under the bark of stems, causing dieback of infested trees, are particularly harmful (Panzavolta and Tiberi 2010).

Pissodes castaneus is a species commonly found in Europe, especially in northern Italy, Austria, Germany, in the Asian part of Russia and Turkey, as well as in North Africa (CABI 2010; Panzavolta and Tiberi 2010; Santolamazza-Carbone et al. 2011). In 2001, it was introduced to South America, where it was initially described in Brazil, Argentina, Uruguay and Chile (Lede et al. 2011). In South America, it damages Pinus taeda L. and Douglas fir Pseudotsuga menziesii (Mirb.) Franco; in Europe many species of pines, primarily $P$. sylvestris and, in the Mediterranean region, $P$. pinaster Aiton and P. pinea L. In Poland P. castaneus is commonly found in $P$. sylvestris plantations and thickets. In the second half of the twentieth century, it did not cause considerable losses economically and has therefore not been studied in this regard. From 2000 to 2015, the area of its occurrence increased in Europe, including Poland, to over 8,000 ha per year, causing the death of young infested forests (Milewski 2015).

So far, there are no methods to reduce populations of $P$. castaneus, except the practiced method of uprooting and burning of trees inhabited by the pest. Until recently, Polish regulations on the use of pesticides allowed for the testing and application of many products registered for the protection of forests against the weevils. Most of this work focused on the efficacy assessment of new formulations registered against the large pine weevil Hylobius abietis L. (Coleoptera, Curculionidae), which is considered as the most dangerous pest of one- to three-year-old coniferous plantations (Örlander 1997, Skrzecz 1998, Långstrom and Day 2004). The lack of chemical methods, which can be applied in the crop protection against $P$. castaneus and the fact that populations can last for many years, justified the undertaking of studies for developing a chemical method to reduce the number of pest populations in forest plantations and thickets. Alpha-cypermethrin, formulated as Fastac 100 EC (10 g of active ingredient $\mathrm{l}^{-1}$, producer BASF), has been used for many years in forest protection against weevils, mainly $H$. abietis (Głowacka et al. 1991). In 2013, a new formulation of alpha-cypermethrin, Fastac Forest 15 SC (15 of active ingredient $1^{-1}$ ), was registered in Europe. This product is used as a water emulsion in a concentration of $4 \%$ for dipping the seedlings before planting or spraying after planting to guarantee protection against $H$. abietis beetles. Preparations based on cypermethrin and its derivatives are currently the only insecticides permitted to protect forest crops against weevils in Poland. They are contact insecticides and paralyse the nervous system, causing, in the case of $H$. abietis beetles, death within two to three days (Garbaliński 1995). Thus this study was conducted to evaluate the insecticidal activity of alpha-cypermethrin against the beetles of $P$. castaneus and the assessment of its efficacy in the protection of Scots pine against this pest. The scope of this work carried out in 2012-2013 included testing of insecticide activity under laboratory conditions and field spraying of trees.

\section{Material AND MEthods}

The $P$. castaneus beetles used in laboratory experiments were collected in April and May 2013 during their feeding on shoots of five-year-old Scots pines growing in central Poland (52 03’34.9' N; 21 23’11.5” E). Alphacypermethrin (formulated as Fastac Forest 15 SC) was tested in five water concentrations prepared by serial dilutions: $1.0,0.1,0.01,0.001$, and $0.0001 \%$, which corresponded to a content of the active ingredient from $1.5^{-2}$ to $1.5^{-6} \mathrm{~g}$ in $1 \mathrm{ml}$. The twigs collected from Scots pine trees on which the beetles fed were then divided into sections (5 $\mathrm{cm}$ long and $1 \mathrm{~cm}$ in diameter) without needles, dipped for five seconds in the above-mentioned concentrations of alpha-cypermethrin and placed on aluminum foil to air-dry. Control-untreated twigs were dipped in water. The prepared shoots were placed individually in Petri dishes (height $1.5 \mathrm{~cm}, 9 \mathrm{~cm}$ in diameter) with one beetle. After three days, the twigs were replaced with untreated ones. In each variant (five concentrations and one untreated) were tested 45 beetles, a total of 270 beetles. The experiment was conducted during seven days at $20^{\circ} \mathrm{C}, 70 \% \mathrm{RH}$ and a photoperiod of 16:8 (L:D) h. Insect mortality was estimated each day and based on the results, $\mathrm{LC}_{50}$ (concentration required to cause $50 \%$ mortality) was calculated using probit regression analysis of alpha-cypermethrin concentrations that have been logarithmically transformed according 
to the Finney method (1962) using the BioStat Pro 5.9.8. program (AnalystSoft Inc.).

Field experiments were performed according to the procedure EPPO PP 1/127 (2) prepared for H. abietis and modified for $P$. castaneus.

Field treatments were performed in 2014 in central Poland (Forest District Celestynów: 52 04'50.6" N; $21^{\circ} 20^{\prime} 54.0^{\prime}$ ' E) in four-year-old Scots pine plantations in which the $P$. castaneus were found feeding on trees in April of the same year. Alpha-cypermethrin was tested in the form of a water emulsion of Fastac Forest 15 $\mathrm{SC}$ in the concentrations 2 and $4 \%$. Spraying was performed in the second half of May, i.e. during the period of egg laying by P. castaneus females. The treatments consisted of spraying the parts of the stems from the root collars to a height of about $20 \mathrm{~cm}$, where the females lay eggs and the larvae hatch. The liquid was applied with the use of the knapsack sprayer SOLO 425, at $0.4 \mathrm{MP}$ and a dose of approximately $100 \mathrm{~mL}$ of preparation per tree. The comparative control consisted of trees sprayed with the same dose of water. In each variant of the experiment (two concentrations of insecticide and untreated), 100 trees were sprayed in the spatial distribution of 20 trees in five rows (repetitions). The efficacy of treatments was estimated after six months (the second half of September) based on the numbers of trees with symptoms of colonization by P. castaneus: yellow needles, upper shoots hanging down and resin leaks on the stems. These trees were taken out and stripped in the laboratory, and the larvae located on the stems from the root collar to a height of $20 \mathrm{~cm}$ were counted. The numbers of seedlings colonized by the pest as well as the numbers of its larvae in all variants of experiment were analysed using Kruskal-Wallis test with an adopted significance level of $P \leq 0.05$, followed by post-hoc test (multiple comparisons of mean ranks for all groups) to find treatment effects that are significantly different from each other. The Statistic v.10 $\left(\right.$ StatSoft $\left.^{\circledR}\right)$ package was used in the analysis.

\section{Results AND DISCUSSION}

The laboratory experiment demonstrated a systematic increase in mortality of $P$. castaneus beetles in all variants of insects reared on twigs dipped in alpha-cypermethrin (Fig. 1).

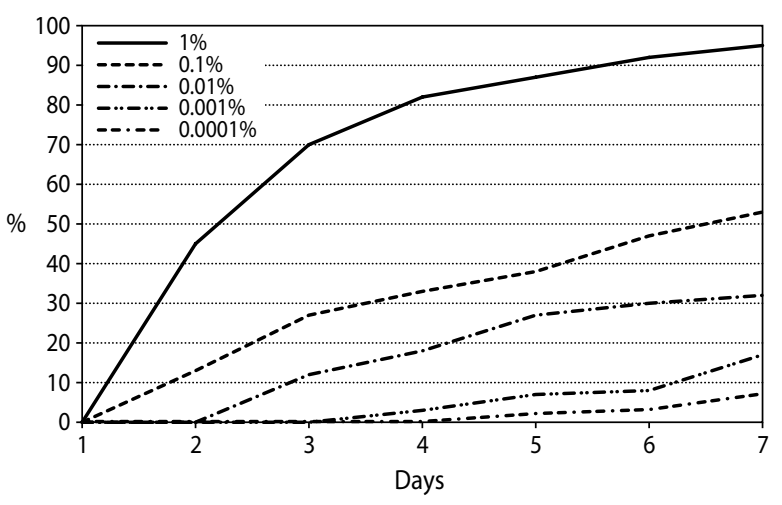

Figure 1. Cumulative mortality of Pissodes castaneus larvae feeding on Pinus sylvestris twigs treated with different concentrations of alpha-cypermethrin

The mortality of insects increased proportionally with increasing insecticide concentrations and was highest in the group of beetles that fed on the twigs treated with $1 \%$ of alpha-cypermethrin. After 24 hours of insect feeding on twigs dipped in 1.0 and $0.1 \%$, beetle mortality increased respectively to 45 and $13 \%$ and survived insects showed signs of paralysis. At that time, in other variants $(0.01-0.0001 \%)$, there were no signs of insect paralysis and the presence of excrements testified the insect feeding. After two days of feeding, the beetles were found dying on twigs treated with a concentration of $0.01 \%$. On the last day of the experiment, the insect mortality had exceeded $50 \%$ only in variants in which the beetles fed on twigs treated with the highest concentrations of alpha-cypermethrin (1.0, $0.1 \%)$. In other variants mortality reached $7 \%$ (concentration $0.0001 \%$ ) to $32 \%$ of insects $(0.01 \%)$. There were no dead individuals in the control experiment. The final $\mathrm{LC}_{50}$ was $0.266 \%$ with a standard error of $0.043 \%$. In the available literature, there is no information on the impact of pyrethroides (including alpha-cypermethrin) on P. castaneus. A study of this scope were primarily focused on the white pine weevil Pissodes strobi (Peck), a pest of white pine (Pinus strobus L.) and 10 species and hybrids of spruce (Picea spp.) (Russel et al. 1990, Alfaro et al. 1995), as well as the large pine weevil Hylobius abietis, which damages young coniferous trees. DeGroot and Helson (1993) exposed P. strobus weevils to white pine twigs sprayed with permethrin and observed the knockdown of insects with $\mathrm{LC}_{50}$ of 0.053 and $0.095 \mu \mathrm{g} / \mathrm{cm}^{2}$ of twig bark after, respectively, 1 and 14 days. Similar to presented results, Malinowski (1995) obtained similar 
results, who stated up to $90-100 \%$ mortality of $H$. abietis beetles reared during 10 days on Scots pine twigs treated with alpha-cypermethrin with concentrations: $0.0125,0.025,0.05 \%$.

Assessment of colonization of trees treated with alpha-cypermethrin formulated as Fastac Forest 15 $\mathrm{SC}$ was carried out six months after the treatment and showed statistical differences between the mortality of Scots pines in individual variants of experiment (Kruskal-Wallis test $H=12.321, p<0.0021$ ) (Tab. 1). The lowest number of trees killed by $P$. castaneus was found in the plot sprayed in the concentration of $4 \%$. More than twice as many dead trees were on plots protected with the insecticide in the concentration of $2 \%$. Most trees killed by the insect were found in the untreated control variant. Only larvae of $P$. castaneus were found in the stems of observed trees. Usefulness of alpha-cypermethrin formulated as Fastac 100 EC in concentration of $1 \%$ was confirmed by Korczyński (2001a, b) who observed 2.5-fold reduction of numbers of treated trees that were damaged by H. abietis. He also compared the extent of bark damages on treated and untreated trees and found more than 10 -fold reduction of area eaten by the large pine weevils.

Table 1. Colonization of Pinus sylvestris trees treated with 2 and $4 \%$ of alpha-cypermethrin by Pissodes castaneus

\begin{tabular}{|c|c|c|c|}
\hline \multirow{2}{*}{ Treatment } & $\begin{array}{c}\text { Mean ( } \pm \text { SD) } \\
\text { number of dead } \\
\text { trees }\end{array}$ & \multicolumn{2}{|c|}{$\begin{array}{c}\text { Mean ( } \pm \text { SD) number } \\
\text { of } P \text {. castaneus larvae } \\
\text { found on the stem section } \\
(20 \text { cm length) }\end{array}$} \\
\cline { 3 - 4 } & $9.4 \pm 1.6^{\mathrm{a}^{*}}$ & $2.6 \pm 1.1^{\mathrm{a}}$ & $2.8 \pm 1.6^{\mathrm{a}}$ \\
\hline $4 \%$ & $4.4 \pm 1.1^{\mathrm{b}}$ & $1.6 \pm 0.7^{\mathrm{a}}$ & $5.4 \pm 1.2^{\mathrm{b}}$ \\
\hline untreated & $16.0 \pm 5.4^{\mathrm{c}}$ & $8.0 \pm 2.3^{\mathrm{b}}$ & $1.25 \pm 0.4^{\mathrm{c}}$ \\
\hline
\end{tabular}

* Different letters show statistical differences at $p=0.05$.

Treatments resulted in reducing the intensity of colonization of trees by the pest. In the trees sprayed with alpha-cypermethrin, there were three- to fourfold less living larvae than under the bark of unsprayed trees. Statistical analyses showed no differences between the numbers of the living larvae in trees treated with both concentrations of alpha-cypermethrin and confirmed the differences compared to untreated trees $(H=36.129 ; p<0.0001)$. Also dead $P$. castaneus larvae were found in all groups of experimental trees. The mortality of larvae statistically differed depending on treatment $(H=38.223 ; p<0.0001)$. Most dead larvae were found in the feeding tunnels in the trees treated with an insecticide concentration of $4 \%$. Twice less numbers of dead larvae were found after removing the bark from the trees sprayed with a $2 \%$ concentration of the insecticide. The death of larvae in treated trees was most likely caused by their contact with the insecticide, because there was no sign of infestation of larvae by parasitoids. The mortality of pest larvae developing in untreated trees was the lowest and caused by parasitoids from the Braconidae family, which are the main factor causing a reduction of $P$. castaneus populations (Kenis et al. 1996, 2004).

\section{Conclusions}

- Alpha-cypermethrin used as Fastac Forest 15 SC caused higher mortality (up to $95 \%$ ) of $P$. castaneus beetles rearing on $P$. sylvestris twigs treated with insecticide.

- Spraying of four-year old P. sylvestris trees with alpha-cypermethrin resulted in the reduction of numbers of trees colonized by $P$. castaneus and led to the higher mortality of pest larvae developing in the infested pines.

- The results indicate the possibility of using alphacypermethrin in the protection of forests against $P$. castaneus and can be the basis for the development of chemical methods used in forest management.

\section{Acknowledgements}

The experiments were financed by General Directorate of State Forests in Poland, project no. BLP-362.

\section{References}

Alauzet C. 1990. Population Dynamics of the pine pest Pissodes notatus (Col.: Curculionidae). Entomophaga, 35, 36-42.

Alfaro R.I., Borden J.H., Fraser R.G., Yanchuk A. 1995. The white pine weevil in British Columbia: Basis 
for an integrated pest management system. Forestry Chronicle, 71, 66-73.

CABI. 2011. Commonwealth Agricultural Bureau International (CABI), Wallingford.

De Groot P., Helson B.V. 1993. Efficacy and timing of insecticide sprays for control of white pine weevil (Coleoptera: Curculionidae) in high-value pine plantations. Journal of Economic Entomology, 86, 1171-1177.

Finney D.J. 1962. Probit Analysis. Cambridge University Press, Cambridge, England.

Garbaliński P. 1995. Biological activity of zetacypermethrin - new insecticidal substance from pyrethroides (in Polish with English summary). Sylwan, 139, 29-36.

Głowacka B., Lech A., Wilczyński W. 1991. Application of deltamethrin for spraying or dipping to protect Scots pine seedlings against Hylobius abietis L. and logs against Tomicus piniperda L. Annals of Forest Science, 48, 113-117.

Kenis M., Hulme M.A., Mills N.J. 1996. Comparative developmental biology of populations of three $\mathrm{Eu}-$ ropean and one North American Eubazus spp. (Hymenoptera: Braconidae), parasitoids of Pissodes spp. weevils (Coleoptera: Curculionidae). Bulletin of Entomological Research, 86, 78-83.

Kenis M., Wegensteiner R., Griffin Ch. 2004. Parasitoids, predators, nematodes and pathogens associated with bark weevil pest. In: Bark and wood boring insects in living trees in Europe, a synthesis (eds.: F. Lieutier, K.R. Day, J.-C. Grégoire, H.F. Evans). Springer, Berlin, 395-414.

Korczyński I. 2001a. Usefulness of the insecticides Marhal 250 EC and Fastac 10 EC for the protection of pine trees (Pinus sylvestris L.) against damages caused by large pine weevil Hylobius abietis (L.) (in Polish with English summary). Sylwan, 145 (7), $55-59$.

Korczyński I. 2001b. Effect of selected insecticides on the feeding by large pine weevil Hylobius abi- etis (L.) on the shoots of pine trees (Pinus sylvestris L.) (in Polish with English summary). Sylwan, 145 (7), 61-64.

Långstrom B., Day K.R. 2004. Damage, control and management of pine weevils. In: Bark and wood boring insects in living trees in Europe, a synthesis (eds.: F. Lieutier, K.R. Day, J.-C. Grégoire, H.F. Evans). Springer, Berlin, 395-414.

Lede E.T., Filho W.R., Penteado S.R.C., Zaleski S.M. 2010. Pissodes castaneus (De Geer, 1775) (Coleoptera, Curculionidae), the bark pine weevil: a pest or a biological indicator? USDA Research Forum on Invasive Species, GTR-NRS-P-75, 95.

Malinowski H. 1995. Action of insecticides on forest pest insects. II. Response of large pine weevil ( $\mathrm{Hy}$ lobius abietis L.) to insecticides at different ways of intoxication (in Polish with English summary). Prace IBL, Ser. A, 785, 43-57.

Milewski W. 2015. Forests in Poland 2015. Centrum Informacyjne Lasów Państwowych, Warsaw.

Örlander G., Nilsson U., Nordlander G. 1997. Pine weevil abundance on clear-cuttings of different ages: a 6-year study using pitfall traps. Scandinavian Journal of Forest Research, 12, 225-240.

Panzavolta T., Tiberi R. 2010. Observations on the life cycle of Pissodes castaneus in central Italy. Bulletin of Insectology, 63 (1), 45-50.

Russel G.M., Kenneth H.W., Norman E.J. 1990. Damage by the sitka spruce weevil (Pissodes strobi) and growth patterns for 10 spruce species and hybrids over 26 years in the Pacific Northwest. USDA Forest Service, Northern Research Station, Research Paper PNW-RP-434.

Santolamazza-Carbone S., Pestana M., Vega J.A. 2011. Post-fire attractiveness of maritime pines (Pinus pinaster Ait.) to xylophagous insects. Journal of Pest Science, 84, 343-353.

Skrzecz I. 1998. Weevils affecting reforestation in Poland. General Technical Report, NE-247, 347. 